\title{
Efeito do tipo de ordenha sobre os parâmetros físicos da glândula mamária e exame do leite de cabras da raça Saanen
}

Jean Silva Ramos ${ }^{[]^{3}}$, Viviani Gomes ${ }^{[a]}$, Mariana Porto Matazo ${ }^{[a]}$, Cynthia Pereira da Costa e Silva ${ }^{[a]}$, Vinicius Alvim Passos Baldacim $^{[a]}$, Karina Medici Madureira ${ }^{[b]}$

\footnotetext{
[a] Faculdade de Medicina Veterinária e Zootecnia, Universidade de São Paulo (USP), São Paulo, SP, Brasil

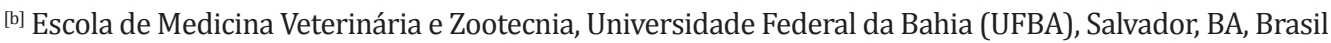

*Autor correspondente

e-mail: jeanramos4@usp.br

\section{Resumo}

A intensificação da indústria leiteira caprina exigiu a tecnificação do sistema de produção com o uso de ordenhadeiras mecânicas, entretanto esse método pode causar alterações na glândula mamária se for utilizado de maneira inapropriada. Assim, esta pesquisa avaliou o efeito da ordenha sobre os parâmetros físicos da glândula mamária (GM) e exame do leite em cabras Saanen. Inicialmente, seis propriedades foram selecionadas para a coleta de material e análise de dados. A similaridade entre os manejos adotados nas seis fazendas foi determinada pela análise de Cluster, verificando-se que duas propriedades apresentavam características diferentes das outras, sendo excluídas desta pesquisa. Desta forma, as quatro propriedades similares foram distribuídas em dois grupos de acordo com o método de ordenha: manual (n = 98 amostras, 49 cabras, duas fazendas) ou mecânico ( $n=122$ amostras, 61 cabras, duas fazendas). Realizou-se o exame físico da GM utilizando as técnicas de inspeção e palpação, além do exame do leite - teste da caneca de fundo escuro, California Mastitis Test - CMT, contagem de células somáticas (CCS) e exame bacteriológico. Foi possível detectar associação entre o método de ordenha com a maioria dos parâmetros físicos da GM: inspeção da GM (P = 0,000), inspeção dos tetos ( $\mathrm{P}=0,002)$, palpação da GM $(\mathrm{P}=0,054)$ e palpação dos tetos $(P=0,036)$. A ordenha mecânica teve associação com a redução do volume da GM (Odds ratio = 6,00), redução do tamanho dos tetos (Odds ratio $=16,19$ ) e consistência firme do parênquima mamário (Odds ratio $=2,39$ ). Por outro lado, o uso de ordenha mecânica representou menor risco para a presença de cisternite $($ Odds ratio $=0,490)$ e aumento de volume da GM (Odds ratio $=0,288)$ em relação à ordenha manual. $\mathrm{A}$ associação entre a CCS e o tipo de ordenha também foi detectada $(\mathrm{P}=0,002)$, observando maior risco de alta celularidade ( $\geq 0,5 \times 10^{6}$ células $/ \mathrm{mL}$ ) em cabras submetidas à ordenha mecânica. A CCS também foi maior em animais submetidos à ordenha mecânica $\left(0,787 \times 10^{6}\right.$ células $\left./ \mathrm{mL}\right)$, enquanto na ordenha manual a CCS 
foi de 0,350 x $10^{6}$ células $/ \mathrm{mL}, \mathrm{P}=0,000$. A ordenha mecânica está associada com alterações nos parâmetros físicos da GM e no leite, achados compatíveis com lesões crônicas. Estas informações apontam para o uso inadequado do equipamento de ordenha nas propriedades de cabras leiteiras e alertam que medidas como o uso de mão de obra qualificada, avaliação dos equipamentos de ordenha e medidas higiênicas sanitárias são necessárias para a obtenção de uma melhor qualidade de leite e saúde nos rebanhos caprinos. 